The Cryosphere Discuss., doi:10.5194/tc-2017-62, 2017

Manuscript under review for journal The Cryosphere

Discussion started: 9 May 2017

(c) Author(s) 2017. CC-BY 3.0 License.

\title{
How unusual was 2015 in the 1984-2015 period of North Cascade Glacier Annual Mass Balance?
}

Mauri S. Pelto

${ }^{1}$ Environmental Science, Nichols College, Dudley, MA 01571 USA

5 Correspondence to: Mauri Pelto (mspelto@nichols.edu)

\begin{abstract}
In 1983 the North Cascade Glacier Climate Project (NCGCP) began annual monitoring 10 glaciers throughout the range, to identify their response to climate change. The annual observations include mass balance, terminus behaviour, and accumulation area ratio (AAR). Annual mass balance (Ba) measurements have been continued on 7 original glaciers that

10 still exist. Two glaciers have disappeared: the Lewis Glacier and Spider Glacier. Foss Glacier was discontinued in 2014 as it has separated into several sections. In 1990, Easton Glacier and Sholes Glacier were added to the annual balance program. This comparatively long record from glaciers in one region conducted by the same research program using the same methods offers some useful comparative data to place the impact of regional climate warmth of 2015 in perspective. The mean annual balance of the North Cascade glaciers is reported in water equivalent thicknesses to the World Glacier Monitoring Service

15 (WGMS). From 1984-2015 the mean Ba is $-0.54 \mathrm{ma}^{-1}$, ranging from -0.44 to $-0.67 \mathrm{ma}^{-1}$ for individual glacier's. This is equivalent to the WGMS global average for this period of $-0.56 \mathrm{ma}^{-1}$. The cumulative loss of $17.2 \mathrm{~m}$ w.e. and $\sim 19 \mathrm{~m}$ of ice thickness represents more than $30 \%$ of the volume of the glaciers. In 2015 the mean Ba of nine North Cascade glaciers was $-3.10 \mathrm{~m}$ w.e., the most negative in the 32 year record, with 2005 the previous maximum loss at $-2.84 \mathrm{~m}$. The mean AAR of $3 \%$ was likewise a minimum, previous minimum was $16 \%$ in 2005 . The correlation coefficient of Ba is above 0.80 between

20 all glaciers including the USGS benchmark glacier, South Cascade Glacier. This indicates that the response is regional and not controlled by local factors. The similar mass balance losses in alpine glacier regions globally suggest global climate change is the principal driving force.
\end{abstract}

\subsection{Introduction}

Glaciers have been studied as sensitive indicators of climate for more than a century (Bojinski et al. 2014). Annual mass 25 balance measurements are the most accurate indicator of short-term glacier response to climate change (Zemp et al, 2015; WGMS, 2015). The WGMS (2015) has recognized that changes in glacier mass are a key aspect of glacier monitoring, providing important information for assessing climatic changes, water resources, and sea level rise and has maintained the most extensive data set on global glacier mass balance. For the IGY in 1957 a number of benchmark glaciers around the 
The Cryosphere Discuss., doi:10.5194/tc-2017-62, 2017

Manuscript under review for journal The Cryosphere

Discussion started: 9 May 2017

(c) Author(s) 2017. CC-BY 3.0 License.

world were chosen where mass balance would be monitored. This network has proven valuable, but in many areas the number of glacier is limited, for example. The WGMS has been working to expand the number of glaciers being monitored in-situ and reporting annual data WGMS (2015). The WGMS has recognized the long term programs with consistent measurement programs as reference glaciers (Zemp et al, 2015). There are two reference glaciers in the North Cascades and in the conterminous United States, South Cascade Glacier (Fig. 1) monitored by the USGS (Fountain et al, 1991) and Columbia Glacier monitored by NCGCP. Glacier mass balance varies due to geographic characteristics such as aspect, elevation and location with respect to prevailing winds. Since no single glacier is representative of all others to understand the causes and nature of changes in glacier surface mass balance throughout a mountain range, it is necessary to monitor a significant number of glaciers (Fountain et al, 1991).

The North Cascade region contains more than 700 glaciers, which are important to summer water supply (Post et. al., 1971; Granshaw and Fountain, 2006). The North Cascade Glacier Climate Project (NCGCP) was founded in 1983 to monitor 10 glaciers throughout the range and identify the response of North Cascade Range, Washington glaciers to regional climate change (Pelto, 1988). The annual observations include mass balance, terminus behaviour, glacier surface area and accumulation area ratio (AAR). Annual mass balance $(\mathrm{Ba})$ measurements have been continued on 7 original glaciers that still exist: Columbia, Daniels, Ice Worm, Lower Curtis, Lynch, Rainbow and Yawning. Two glaciers have disappeared: the Lewis Glacier and Spider Glacier (Pelto, 2008). One other glacier Foss Glacier has declined to the extent that continued measurements have been suspended. In 1990, Easton Glacier and Sholes Glacier were added to the annual balance program to offset the loss of Spider and Lewis Glacier. All Ba, AAR and terminus change data are reported annually to the World

20 Glacier Monitoring Service (WGMS). One glacier, Columbia Glacier is a reference glacier for the WGMS mass balance series. This network combined with South Cascade Glacier is the also the most spatially concentrated group of glaciers where $\mathrm{Ba}$ has been monitored for at least 25 years, which provides a unique chance to compare the mass balance records to each other and climate records. This paper examines the exceptional 2015 mass balance year, placing the year in context of the thirty-two year mass balance record and local climate records.

\subsection{Climate}

The North Cascade region has a temperate maritime climate with mild year-round temperatures, abundant winter precipitation, and dry summers (Mote, 2003). The two key climate variables for the temperate maritime glaciers are accumulation season precipitation (November-April) and ablation season temperature (May-September) (Pelto, 1988; Josberger et al. 2007). A climate warming of $0.8{ }^{\circ} \mathrm{C}$ in mean annual temperature has been observed from 1901-2012 in the 30 North Cascades (Abatzoglou et al, 2014). The warming has accelerated to $+0.20 \mathrm{C}$ per decade for the 1980-2012 period. Every season except spring has experienced warming, particularly during the 1980-2012 period (Abatzoglou et al, 2014). 
The Cryosphere Discuss., doi:10.5194/tc-2017-62, 2017

Manuscript under review for journal The Cryosphere

Discussion started: 9 May 2017

(c) Author(s) 2017. CC-BY 3.0 License.

Approximately 70\% of the region's precipitation occurs during the wet season (October-April) when the North Cascades are on the receiving end of the Pacific storm track (Elsner et al, 2010). From late spring to early fall, high pressure to the west keeps the Pacific Northwest comparatively dry. Occasionally in the winter warm fronts elevate temperatures, resulting in

5 higher freezing levels, leading to rainfall even at glacier elevations. Rain on snow events have increased in frequency (Elsner et al, 2010), this has led to an increase in the ratio of precipitation falling as rain versus snow, reducing snowpack storage efficiency (Mote et al 2008; Pelto, 2008). For the six USDA SNOTEL stations utilized in this study mean April 1 SWE declined 29\% from 1946-2014. During the same period winter precipitation has increased slightly. The change in SWE is comparable with the change in snowpack storage efficiency indicating this is the primary cause of reduced April 1 SWE at

10 North Cascade SNOTEL stations. The freezing level is a key factor in determining snowpack storage efficiency and a North American Freezing Level Tracker was developed by Abatzoglou (2011) that is used here for comparison of the freezing level during the winter for Mount Baker.

The other key factor in glacier behaviour is the amount of ablation, which is primarily controlled by air temperature. That

15 air temperature is the key is indicated by the success of degree day factors (DDF) for assessing glacier ablation on glaciers in this region (Shea et al, 2008). The majority of ablation takes place during the June-September period, and nearly all ablation during the May-September period. The most reliable weather station in the region is Diablo Dam, which is used for DDF derivation on South Cascade Glacier (Rasmussen, 2009). An examination of trends in summer temperature at this station indicates a nearly identical pattern, for May-September and June-September. Six of the ten warmest summers during the

20 1946-2014 period have occurred since 2003. The long term summer warming is $0.7^{\circ} \mathrm{C}$ at Diablo Dam. The average JuneSeptember temperature from $2003-2014$ is $0.6^{\circ} \mathrm{C}$ above the mean for the $1946-2002$ period.

Bitz and Battisti (1999) noted the importance of PDO and MEI-ENSO to glaciers in the region, with PDO having a greater influence during the 1960-1995 period. Josberger et al (2007) indicate that the importance of PDO has declined recently.

25 Pelto (2008) used the indices as a first order forecast for annual glacier mass balance. Finding the impact was strongest when both indices were positive or negative.

The PDO Index is the leading principal component of North Pacific monthly sea surface temperature variability, poleward of 20N (Mantua et al., 1997). During the positive PDO phase warm weather is favored in the Pacific along the northwest coast 30 and over the Pacific Northwest. During the negative phase cool ocean water is found off the northwest coast and cooler temperatures across the Pacific Northwest (Mantua et al., 1997). In the past century: "cool" PDO regimes prevailed from 1890-1924 and again from 1947-1976, while "warm" PDO regimes dominated from 1925-1946 and from 1977-1998 (Mantua et al., 1997). 
The Cryosphere Discuss., doi:10.5194/tc-2017-62, 2017

Manuscript under review for journal The Cryosphere

Discussion started: 9 May 2017

(c) Author(s) 2017. CC-BY 3.0 License.

The El Niño/Southern Oscillation (ENSO) phenomenon is the most observable of the atmospheric circulation indices that lead to year-to-year climate variability. ENSO positive events (El Nino) herald abnormally warm sea surface temperatures (SST) over the eastern half of the equatorial Pacific. La Niña, is the opposite phenomenon, indicative of abnormally cold SST in the eastern half of the equatorial Pacific. ENSO is an east-west atmospheric pressure see-saw that directly affects

5 tropical weather around the globe and indirectly impacts a much larger area (Wolter and Timlin, 1998). The ENSO multivariate index used here is based on the principal observed climate variables over the tropical Pacific. The index is a weighted average of the main ENSO features contained in the following six variables: sea-level pressure, the east-west and north-south components of the surface wind, SST, surface air temperature, and total amount of cloudiness (Wolter and Timlin, 1998). Positive ENSO values are usually accompanied by sustained warming of the central and eastern tropical

10 Pacific Ocean. Negative values of the ENSO index are associated with stronger Pacific trade winds and warmer sea temperatures to the north of Australia (Wolter and Timlin, 1998).

\subsection{Climate in 2015}

The 2015 winter accumulation season featured 51\% of mean (1984-2014) winter snow accumulation at six long-term USDA SNOTEL stations in the North Cascades; Fish Creek, Lyman Lake, Park Creek, Rainy Pass, Stevens Pass, and Stampede

15 Pass. This was exceptional in being the second lowest of the 32 years of the mass balance observation series. The winter season was exceptional for warmth, being the warmest winter season in the state of Washington (NOAA, 2015). The freezing level was high averaging $1645 \mathrm{~m}$ in the Mount Baker region from November-March compared to an average of $1077 \mathrm{~m}$ (Abatzoglou, 2011). No previous year exceeded a mean freezing level of $1500 \mathrm{~m}$ since the record began in 1948 (Figure 2). The result was snowpack at the six SNOTEL sites averaging $0.52 \mathrm{~m}$ w.e., $51 \%$ of the 1984-2014 average. The 20 minimum snowpack was in 2005 with $44 \%$ of mean snowpack, that year had less precipitation. The limited snowpack was not due to reduced precipitation as November-April precipitation at Diablo Dam and Concrete was 5-10\% above the 19842014 mean. Mote et al (2008) noted a decline in snowpack storage efficiency in the Pacific Northwest, the ratio between total precipitation and April 1 retained snowpack SWE. Pelto (2008) used the Diablo Dam and Concrete weather stations for total precipitation for November-March, the period of accumulating snowpack at the six SNOTEL sites with long term

25 records in the North Cascades, to determine snowpack storage efficiency. In 2015 the snowpack storage efficiency was the lowest with the mean April 1 retained SWE at six long-term SNOTEL stations being 19\% of the November-March precipitation, compared to a 1984-2014 mean of 41\%, the second lowest year was 2005 at $20 \%$. The snowline by the end of April 2015, the end of the typical accumulation season, in the Mount Baker region was $1400 \mathrm{~m}$, versus the $800 \mathrm{~m}$ average.

30 In 2015 the mean May-September temperature at Diablo Dam was 2.2 C above the long term mean, and the second warmest to 1958 in the record from 1950-2015. For June to September the mean temperature was $2.0 \mathrm{C}$ above the long term mean and was also second to 1958 as the warmest. The mean 2015 July-August temperature recorded at the automatic weather station $100 \mathrm{~m}$ from the terminus of Sholes Glacier was $10.7 \mathrm{C}$. The combination of the warmest melt season in over 50 years 
The Cryosphere Discuss., doi:10.5194/tc-2017-62, 2017

Manuscript under review for journal The Cryosphere

Discussion started: 9 May 2017

(c) Author(s) 2017. CC-BY 3.0 License.

and the second lowest accumulation season snowpack in the last 30 years was a good indication that glacier mass balance would be quite negative.

In 2015 sea surface temperature waters that had developed in the winter of 2013/14 persisted off the coast of the Pacific

5 Northwest, with anomalies generally exceeding 2 C (Bond et al., 2015; Di Lorenzo and Mantua, 2016). Such conditions are associated with a positive PDO and warm air temperatures in the Pacific Northwest (Bond et al., 2015). From the winter of 2013/14 to 2014/15 the northeast Pacific experienced the largest marine heatwave ever recorded (Di Lorenzo and Mantua, 2016). In 2015 the warmest SST paralleled the entire Pacific North American coast exhibiting a PDO pattern (Di Lorenzo and Mantua, 2016).

A comparison of annual, winter and summer values for PDO 1984-2015 indicate that 2015 ranks in the top five for PDO for each seasonal measure. Examining the 1984-2015 period for ENSO indicates that in 2015 summer and annual values rank in the top 5. The 2015 hydrologic year had the most positive PDO of any year, but ENSO was not the most positive. The combined value of PDO + ENSO in 2015 ranked in the top five for both annual and seasonal rankings during the 1984-2015

15 period. Positive values for both ENSO and PDO are inversely related to glacier mass balance and also reinforce each other (Pelto, 2008). This illustrates that 2015 was predisposed for negative annual balance based solely on climate indices. The link between PDO and ENSO forced the anomalous atmospheric and sea surface temperature event in 2015 (Di Lorenzo and Mantua, 2016).

20 Overall 2015 was exceptional in terms of sea surface temperature in the northeast Pacific, air temperature in the North Cascade region and the positive values of the PDO, while ENSO was significantly positive.

\subsection{Glacier Mass Balance Methods}

Annual surface mass balance is the difference between accumulation of snow and ice in winter and loss of snow and ice by ablation in summer. It is typically measured on a water year basis, approximately beginning October 1 and ending September

2530 in the northern hemisphere yielding an annual mass balance (Ba) (Cogley et al (2011).

Since 1984, NCGCP has monitored the Ba of 9-10 glaciers every year (Pelto, 1996; Pelto and Riedel, 2001; Pelto and Brown, 2012). Seven glaciers have a 32-year record; Columbia, Daniels, Ice Worm, Lower Curtis, Lynch, Rainbow and Yawning. Foss Glacier has a 30 year record 1984-2013 and was discontinued due to the glacier separating into several 30 sections. Sholes and Easton Glacier have a 26-year record 1990-2015. The glaciers represent a range of geographic characteristics and span the North Cascade Range (Table 1 and Figure 1). Key geographic variables are orientation of the 
The Cryosphere Discuss., doi:10.5194/tc-2017-62, 2017

Manuscript under review for journal The Cryosphere

Discussion started: 9 May 2017

(c) Author(s) 2017. CC-BY 3.0 License.

glacier, mean elevation, accumulation sources and distance to the mountain ranges watershed and climate divide. Columbia Glacier in 2015 is one of the 37 reference glaciers used by the WGMS.

NCGCP measures conditions on a glacier near the time of minimal mass balance at the end of the water year, using a fixed

date method. Measurements are made at the same time each year using the same methods from late July to mid-August and again in late September-early October near the end of the ablation season. Any additional ablation that occurs after the last visit to a glacier is measured during the subsequent hydrologic year. The methods are reviewed in detail by Pelto (1996, 1997), Pelto and Riedel (2001), Pelto (2008) and Pelto and Brown (2012).

10 NCGCP methods emphasize surface mass balance measurements with a relatively high density of sites on each glacier (>100 sites $\mathrm{km}^{-2}$ ), consistent measurement methods, applied on fixed dates, at fixed measurement locations with consistent supervision (Pelto, 1996; Pelto and Riedel, 2001). The use of a high measurement density and consistent methods generates errors resulting from an imperfectly representative measurement network that are largely consistent and correctable, the error range has been observed at $\pm 0.10-0.15 \mathrm{ma}^{-1}$ (Pelto, 2000).

\section{4.0 Results:}

\subsection{Annual Mass Balance}

Glaciers in the North Cascades exhibit consistent Ba responses to climate from year to year (Pelto and Riedel, 2001; Pelto and Brown, 2012). Figure 3 illustrates the closely correlated pattern of Ba fluctuations from 1985 to 2015. In most years, all glaciers respond in step with each other to variations in winter retained snowpack and summer temperature. There is a mean

20 annual range of $0.8 \mathrm{~m}$ from the maximum to the minimum $\mathrm{Ba}$ in a given year, but the inter-annual trend is the same for each glacier. This regional response is indicated by the high cross correlation values of Ba between individual glaciers ranging from $\mathrm{r}^{2}$ of 0.80 to 0.98 between each glacier pair, including the South Cascade Glacier monitored by the USGS (Table 2) (Bidlake et al, 2010). Data for 2013-2015 has not been finalized for South Cascade Glacier; hence the comparison period ends in 2012 for this glacier.

25

The mean Ba has been $-0.54 \mathrm{ma}^{-1}$ for the 1984-2015 period on the glaciers monitored annually, ranging from a maximum of $-0.44 \mathrm{ma}^{-1}$ to a minimum of $-0.67 \mathrm{ma}^{-1}$ (Table 3). The mean Ba, $-0.54 \mathrm{ma}^{-1}$ for North Cascade glaciers during the 1984-2015 period is quite similar to the WGMS global reference glacier mean Ba of $0.56 \mathrm{ma}^{-1}$ (Figure 6)(WGMS, 2017) The mean cumulative mass balance loss has been $-17.2 \mathrm{~m}$ w.e, which is a 19-20 m of glacier thickness lost. North Cascade glacier 30 average thickness ranges from 30-60 m (Post et al, 1971; Pelto and Hedlund, 2001; Finn et al, 2012). Thus, at least 30\% of the volume of these glaciers has been lost since 1984. Observations by the USGS at South Cascade Glacier indicate that 
The Cryosphere Discuss., doi:10.5194/tc-2017-62, 2017

Manuscript under review for journal The Cryosphere

Discussion started: 9 May 2017

(c) Author(s) 2017. CC-BY 3.0 License.

mean Ba from 1984-2012 is $-0.75 \mathrm{ma}^{-1}$ on South Cascade Glacier, $0.21 \mathrm{ma}^{-1}$ more negative than the glaciers we monitor. South Cascade Glacier had a much less negative mean Ba of -0.15 ma ${ }^{-1}$ from 1956-1975 (Krimmel, 2001).

\subsection{Accumulation Area Ratio}

At regional scales and on specific glaciers there are two common proxies for assessing mass balance without detailed

5 observations. They are the AAR and equilibrium line altitude (ELA) both can be derived from satellite imagery or photographs (Østrem, 1973; Racoviteanu et al, 2008). The ELA is the elevation at which ablation equals accumulation, on temperate alpine glaciers this is coincident with the TSL at the end of the melt season. The ELA is not typically an easily discernible line or elevation on North Cascades glaciers, due to variability of snow accumulation from impacts of wind and avalanche redistribution. AAR is a more accurately determined parameter and a better proxy in this case (Pelto and Brown,

10 2012). Rabatel et al (2008) and Dyurgerov (1996) developed methods to derive mass balance from long term AAR observations. The AAR-Ba method has proven reliable for annual balance estimates (Hock et al., 2007; Racoviteanu et al, 2008; Pelto and Brown, 2012). A comparison of annual AAR and Ba observations in WGMS (2007; 2009) indicate correlation coefficients ranging from 0.70-0.92 for fifteen glaciers with at least 10 years of records. The World Glacier Monitoring Service (WGMS) has adopted the reporting of AAR with mass balance values (WGMS, 2007, 2009) and plotting

15 the relationship for each glacier. A combination of AAR observations and Ba measurements from 1984-2015 on North Cascade glaciers provides an opportunity to assess the relationship for each glacier and the variability between glaciers.

The AAR0 value is the AAR for a glacier with an equilibrium mass balance (Meier and Post, 1962). Braithwaite and Muller (1980) noted that the AAR0 for an alpine glacier with an equilibrium balance averaged 0.67. The mean AAR0 reported for

2089 temperate alpine glaciers to the WGMS was 0.57 (WGMS, 2007: WGMS, 2009). The observed AAR0 on North Cascade glaciers ranges from a low of 0.60 on Ice Worm Glacier to 0.67 on Easton Glacier. The regression line from the plot of the AAR and Ba for the ten North Cascade glaciers indicates a mean AAR0 of 0.64 and a correlation coefficient of 0.89 between AAR and Ba (Fig. 4 and Fig. 5).

\subsection{Annual Mass Balance 2015}

On June $15^{\text {th }}$ when the automatic weather station and discharge station were installed adjacent to Sholes Glacier the snowpack was similar to typical early August snowcover. On Sholes Glacier the AAR fell from 0.55 on July $9^{\text {th }}$ to 0.00 on Sept. 9. In early August the AAR was below 0.10 in on all glaciers except for Easton Glacier Figure (7, 8 and 9). This was the first year since monitoring began in 1984 that the AAR in early August was below 0.25. The result was exposure of 30 older firn layers and a general decrease in albedo. In 2015 of the nine glaciers where Ba was examined the AAR was 0.00 on seven glaciers, 0.05 on Rainbow Glacier and 0.26 on Easton Glacier. This indicates the lack of a significant accumulation 
The Cryosphere Discuss., doi:10.5194/tc-2017-62, 2017

Manuscript under review for journal The Cryosphere

Discussion started: 9 May 2017

(c) Author(s) 2017. CC-BY 3.0 License.

(c) (i)

zone in 2015 for all but Easton Glacier. The mean 2015 AAR of 0.03 is significantly less than the previous low of 0.16 in 2005 and the 1984-2015 mean of 0.53 .

In 2015 the mean Ba of all nine glaciers North Cascade glaciers examined and reporting to the WGMS was $-3.19 \mathrm{~m}, 2.65 \mathrm{~m}$

5 below the long term mean. The second most negative year for Ba was $-2.84 \mathrm{~m}$ in 2005; no other year exceeded $-2 \mathrm{~m}$. The mean Ba 2015 data for WGMS reference glacier network is -1.12 m w.e., the second most negative to 2003 (WGMS, 2017). The mean BA of all WGMS reporting glacier in 2015 was $-1.04 \mathrm{~m}$. of the 11 glaciers globally reporting a loss of more than $3 \mathrm{~m}$, nine were in the state of Washington, including in addition to the NCGCP glaciers Eel Glacier in Olympic National Park and Noisy Creek Glacier in North Cascades National Park reported by the National Park Service (WGMS, 2017), Of

10 the WGMS reference glacier network Columbia Glacier had the most negative balance of any glacier. The Ba continues to trend negatively, both globally and in the North Cascades indicating that instead of approaching equilibrium as the glaciers retreat they continue to be in disequilibrium with current climate (Fig. 6). This mass balance loss represents the loss of 5$10 \%$ of the total glacier volume in a single year.

\section{$15 \quad 5.0$ Climate Correlations}

Examination of Pacific Northwest glacier mass balance for the full period of research for NCGCP and USGS benchmark glaciers indicate that winter balance fluctuations of maritime glaciers dominated the Ba fluctuations (Josberger et al, 2007). Looking at the full period of record 1984-2015it is apparent that summer balances of the benchmark glaciers have become more negative during recent years, a result of warmer and drier summers, summer balance and have taken on a greater role in

20 determining $\mathrm{Ba}$ (Josberger et al, 2007).

Bitz and Battisti (1999) noted the importance of PDO and MEI-ENSO to glaciers in the region, with PDO having a greater influence during the 1960-1995 period. Josberger et al (2007) suggested that there was a decoupling of winter balance and the PDO for the benchmark glaciers in the Pacific Northwest. They used three time periods, 1966-2004, 1966-1988 and 1989-2004, and found a significant change in the relationship between the PDO and the winter balances of Wolverine Glacier, but less so for South Cascade Glacier. Here we use two periods 1984-1998 and 1999-2014 comparing annual mass balance for each glacier to the PDO index for October-April (winter) and the annual mean October-September MEI-ENSO. During the first period the mean correlation was -0.34 for winter PDO and -0.59 for MEI-ENSO. During the latter period the mean correlation increased to -0.54 for winter PDO and -0.66 for MEI-ENSO. The annual MEI-ENSO index remains a

30 better indicator of annual mass balance in the North Cascade Range than winter PDO. The annual PDO index has a significantly lower relation to annual balance than winter PDO. The correlation between the cumulative mass balance records of glaciers in various alpine glaciated regions around the globe, indicate the global climate signal is the dominant driver of mass balance losses (Zemp et al., 2015). 
The Cryosphere Discuss., doi:10.5194/tc-2017-62, 2017

Manuscript under review for journal The Cryosphere

Discussion started: 9 May 2017

(c) Author(s) 2017. CC-BY 3.0 License.

\subsection{Conclusions}

The impact of the warmer temperatures and reduced winter snowpack on North Cascade glaciers has been an average annual balance of $-0.54 \mathrm{~m} / \mathrm{a}$ over the past 32 years. The net loss of $-17.3 \mathrm{~m}$ w.e. represents a significant portion, $30 \%$ of the total glacier volume, resulting in substantial retreat and thinning. The resultant retreat is ubiquitous, rapid and increasing. There is

5 no evidence that North Cascade glaciers are close to equilibrium. Their ongoing thinning indicates that all of the glaciers will continue to retreat in the foreseeable future. In cases where the thinning is substantial along the entire length of the glacier, then no point of equilibrium can be achieved with present climate and the glacier is unlikely to survive (Pelto, 2006). Continued glacier retreat is inevitable, $75 \%$ of the North Cascade glaciers we observe are in disequilibrium and will melt away during this century with the current climate (Pelto, 2010). The loss of glacier area will lead to further declines in 10 summer runoff in glacier fed rivers as the glacier area available for melting in the summer declines (Stahl and Moore, 2006; Pelto, 2015). This will impact salmon in streams such as the Nooksack River (Grah and Beaulieu, 2013).

Data Availability: Annual mass balance data and associated metadata for each glacier is submitted annually to the World Glacier Monitoring Service. This data is made available on their website for the most recent years, every two years the 15 results are published in a glacier mass balance bulletin up until 2011. And currently in a Global Glacier Change Bulletin produced by the WGMS. Current DOI for scientific data (Identifier): 10.5904/wgms-fog-2015-11

http://wgms.ch/products_gmbb/

and

http://wgms.ch/ggcb/

20 The data is also available through a data viewer at:

http://wgms.ch/metadatabrowser.html 
The Cryosphere Discuss., doi:10.5194/tc-2017-62, 2017

Manuscript under review for journal The Cryosphere

Discussion started: 9 May 2017

(c) Author(s) 2017. CC-BY 3.0 License.

\section{References}

Abatzoglou, J.T.: Influence of the PNA on Declining Mountain Snowpack in the Western United States. Int. Journal of Climatology, doi:10.1002/joc.2137, 2011.

Abatzoglou, J.T., Rupp, D.E., and Mote, P.W.: Seasonal Climate Variability and Change in the Pacific Northwest of the United States. J. Climate, 27, 2125-2142, doi: http://dx.doi.org/10.1175/JCLI-D-13-00218.1, 2014.

Bidlake, W.R., Josberger, E.G., and Savoca, M.E.: Modeled and measured glacier change and related glaciological, 10 hydrological, and meteorological conditions at South Cascade Glacier, Washington, balance and water years 2006 and 2007, U.S. Geological Survey Scientific Investigations Report 2010-5143, 2010.

Bitz, C.M. and Battisti, D.S.: Interannual to decadal variability in climate and the glacier mass balance in Washington, Western Canada, and Alaska, Journal of Climate, Vol. 12, 3181-3196, 1999.

15

Bojinski, S., Verstraete, M., Peterson, T., Richter, C., Simmons, A. and Zemp, M.: The concept of Essential Climate Variables in support of climate research, applications, and policy. Bull. Am. Meteorol. Soc., 95(9), 1431-1443 (doi: 10.1175/BAMS-D-13- 00047.1), 2014.

20 Bond, N., Cronin, M., Freeland, H. and N. Mantua, N.: Causes and impacts of the 2014 warm anomaly in the NE Pacific. Geophys. Res. Lett., 42, 3414-3420. doi: 10.1002/2015GL063306, 2015.

Braithwaite, R. J. and Müller, F.: On the parameterization of glacier equilibrium line, IAHS Publication 126, Riederalp Workshop 1978 - World Glacier Inventory, 263-271, 1980.

Cogley JG. and 10 others: Glossary of glacier mass balance and related terms. UNESCO-International Hydrological Programme. IACS.(IHP-VII Technical Documents in Hydrology No. 86, 2011.

Di Lorenzo, E. and Mantua, N.: Multi-year persistence of the 2014/15 North Pacific marine heatwave, Nature Climate 
The Cryosphere Discuss., doi:10.5194/tc-2017-62, 2017

Manuscript under review for journal The Cryosphere

Discussion started: 9 May 2017

(c) Author(s) 2017. CC-BY 3.0 License.

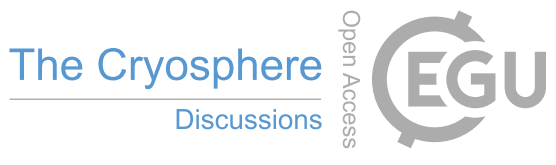

(c) (i)

Dyurgerov, M.: Substitution of long term mass balance data by measurements of one summer. Gletscherkd. Glazialgeol. 32:

177-184, 1996.

Elsner, M.M, Cuo L, Voisin, N., Deems, J., Hamlet, A.F., Vano, J.A., Mickelson, K.E.B., Lee, S.Y., Lettenmaier, D.P., 5 (2010) Implications of 21st century climate change for the hydrology of Washington State. Clim Change, 102(1-2):225-260.

Finn, C.A., Deszcz-Pan, M., and Bedrosian, P.A.: Helicopter electromagnetic data map ice thickness at Mount Adams and Mount Baker, Washington, USA.J. Glaciol. 58 (212): 1133-1143, http://dx.doi.org/10.3189/2012JoG11J098, 2012.

10 Fountain, A., Trabant, D., Bruggman, M.. Ommaney, C., and Monroe, D.: Glacier mass balance standards. EOS, 72(46): 511-514, 1991.

Grah, O. Beaulieu, J.: The effect of climate change on glacier ablation and baseflow support in the Nooksack River basin and implications on Pacific salmonid species protection and recovery. Climatic Change: DOI 10.1007/s10584-013-0747-y, 152013.

Granshaw, F., and Fountain, A: Glacier change (1958-1998) in the North Cascades National Park Complex,Washington, USA. J. Glaciol. 52(177): 251-256, 2006.

20 Josberger, E.G., Bidlake, W.R., March, R.S. and Kennedy, B.W.: Glacier mass-balance fluctuations in the Pacific Northwest and Alaska, USA, Annals of Glaciology, 46, 291-296, 2007.

Krimmel, R.M.: Water, Ice, Meteorological and Speed Measurements at South Cascade Glacier, Washington, 1999 Balance Year. USGS WRI-00-4265, 2001.

25

Mantua, N.J., Hare, S.R., Zhang, Y., Wallace, J.M., and Francis, R.C.: A Pacific interdecadal climate oscillation with impacts on salmon production. Bulletin American Meteorological Society, 78, 1069-1079, 1997.

Mote, P. W.: Trends in snow water equivalent in the Pacific Northwest and their climatic causes. Geophys. Res. Lett., 30, 30 1601, doi:10.1029/2003GL017258, 2003.

Mote, P., Hamlet, A., and Salathe, E.: Has spring snowpack decline in the Washington Cascades? Hydrol. Earth Syst. Sci. 12, 193-206, 2008. 
The Cryosphere Discuss., doi:10.5194/tc-2017-62, 2017

Manuscript under review for journal The Cryosphere

Discussion started: 9 May 2017

(c) Author(s) 2017. CC-BY 3.0 License.

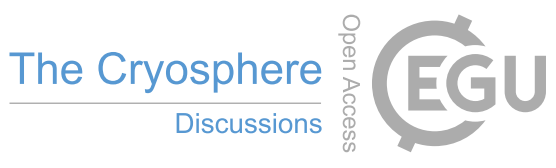

(c) (i)

Meier, M.F., and Post, A.: Recent variations in mass net budgets of glaciers in western North America. IAHS 58: 63-77, 1962.

Østrem, G.: The transient snowline and glacier mass balance in southern British Columbia and Alberta, Canada, Geogr. Ann. 5 A,55, 93-106, 1973.

Pelto, M.S.: The annual balance of North Cascade, Washington Glaciers measured and predicted using an activity index method. J. Glaciol., 34, 194-200, 1988.

10 Pelto, M.S.: Recent changes in glacier and alpine runoff in the North Cascades, Washington. Hydrol. Proc., 10, 1173-1180, 1996.

Pelto, M.S.: Reply to comments of Meier and others on “Annual net balance. of North Cascade glaciers 1984-1994” by M. S. Pelto. J. Glaciol,. 43(143), 193-196, 1997.

15

Pelto, M.S.: The impact of sampling density on glacier mass balance determination. Hydrol. Proc. 14: 3215-3225, 2000.

Pelto, M.S.: The Current Disequilibrium of North Cascades glaciers. Hydrol. Processes. 20, 769-779, 2006.

20 Pelto, M.S.: Impact of Climate Change on North Cascade Alpine Glaciers, and Alpine Runoff. Northwest Science, 82, 65$75,2008$.

Pelto, M.S.: Glacier annual balance measurement, forecasting and climate correlations, North Cascades, Washington 19842006. The Cryosphere 2, 13-21, 2009.

25

Pelto, M.S.: Forecasting Temperate Alpine Glacier Survival from Accumulation Zone Observations. The Cryosphere, 3, 323-350, 2010.

Pelto, M.S.: Climate Driven Retreat of Mount Baker Glaciers and Changing Water Resouorces, Springer Briefs in Climate 30 Studies, Springer, 2015.

Pelto, M.S. and Brown, C.: Mass balance loss of Mount Baker, Washington glaciers 1990-2010. Hydrological Proc. 26(17), 2601-2607, 2012. 
The Cryosphere Discuss., doi:10.5194/tc-2017-62, 2017

Manuscript under review for journal The Cryosphere

Discussion started: 9 May 2017

(c) Author(s) 2017. CC-BY 3.0 License.

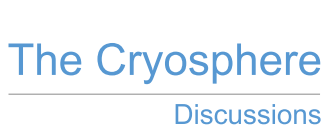

(c) (i)

Pelto, M.S. and Hedlund, C.: The terminus behavior and response time of North Cascade glaciers. J. Glaciol. 47, 497-506, 2001.

Pelto, M. and Riedel, J.: The spatial and temporal variation of mass balance on North Cascade glaciers. Hydrological Proc., 5 15, 3461-3472, 2001.

Post, A., Richardson, D., Tangborn, W.V., and Rosselot, F.L.: Inventory of glaciers in The North Cascades, Washington. US Geological Survey Prof. Paper, 705-A, 1971.

10 Rabatel, A., Dedieu, J., Thibert, E., Letreguilly, A., and Vincent, C.: Twenty-five years of equilibrium-line altitude and mass balance reconstruction on the Glacier Blanc, French Alps (1981-2005), using remote-sensing method and meteorological data. J. Glaciol. 54, 307-314, 2008.

Racoviteanu A, Williams M. and Barry R.: Optical remote sensing of glacier characteristics: A review with focus on the 15 Himalaya. Sensors, 8(5), 3355-3383, doi: 10.3390/s8053355, 2008.

Rasmussen, L.A.: South Cascade Glacier mass balance, 1935-2006. Ann. Glaciol. 50, 215-220, 2009.

Shea, J.M., Moore, R.D. and Stahl, K.: Derivation of melt factors from glacier mass balance records in western Canada. Journal of Glaciology 55 (189), 123-130, doi:10.3189/002214309788608886, 2009.

Stahl, K. and Moore, D.: Influence of watershed glacier coverage on summer streamflow in British Columbia, Canada. Water Resour. Res., 42, W06201 (doi: 10.1029/2006WR005022), 2006.

25 WGMS: Glacier Mass Balance Bulletin No. 9 (2004-2005). Haeberli, W., Hoelzle M. and Zemp, M. (eds.). ICSU(FAGS)/IUGG(IACS)/UNEP/UNESCO/WMO, World Glacier Monitoring Service, University of Zurich, 2007.

WGMS: Glacier Mass Balance Bulletin No. 10 (2006-2007). Haeberli, W., Gartner-Roer, I. Hoelzle M. Paul, F. and Zemp, M. (eds.). CSU(FAGS)/IUGG(IACS)/UNEP/UNESCO/WMO, World Glacier Monitoring Service, University of Zurich, $30 \quad 2009$.

WGMS: Glacier Mass Balance Bulletin No. 11 (2008-2009). Zemp, M., Nussbaumer, S. U., GärtnerRoer, I., Hoelzle, M., Paul, F., and Haeberli, W. (eds.), ICSU(WDS)/IUGG(IACS)/UNEP/UNESCO/WMO, World Glacier Monitoring Service, Zurich, Switzerland, 2011. 
The Cryosphere Discuss., doi:10.5194/tc-2017-62, 2017

Manuscript under review for journal The Cryosphere

Discussion started: 9 May 2017

(C) Author(s) 2017. CC-BY 3.0 License.

(c) (i)

WGMS: Global Glacier Change Bulletin No. 1 (2012-2013). Editors; Zemp, M., Gärtner-Roer, I., Nussbaumer, S.U., Hüsler,

F., Machguth, H., Mölg, N., Paul F., and Hoelzle, M. (eds.), ICSU(WDS)/IUGG(IACS)/UNEP/UNESCO/WMO, World Glacier Monitoring Service, Zurich, Switzerland,2015.

5

WGMS: http://wgms.ch/latest-glacier-mass-balance-data/, WGMS online, available from WGSM, 2017.

Wolter, K., and Timlin, M.: El Niño/Southern Oscillation behaviour since 1871 as diagnosed in an extended multivariate ENSO index. Intl. J. Climatology, 31, 1074-1087, 2011.

10

Zemp, M., Hoelzle, M. and Haeberli W.: Six decades of glacier mass-balance observations: a review of the worldwide monitoring network. Ann. Glaciol., 50(50), 101-111 (doi: 10.3189/ 172756409787769591), 2009.

Zemp, M., and 16 others: Historically unprecedented global glacier decline in the early 21 st century. Journal of Glaciology, 1561 (228), p. 745-762. doi: 10.3189/2015JoG15J017, 2015. 
The Cryosphere Discuss., doi:10.5194/tc-2017-62, 2017

Manuscript under review for journal The Cryosphere

Discussion started: 9 May 2017

(C) Author(s) 2017. CC-BY 3.0 License.

(c) (i)

\begin{tabular}{|c|c|c|c|c|c|}
\hline GLACIER & ASPECT & $\begin{array}{l}\text { AREA } \\
(\mathrm{km} 2)\end{array}$ & ACCUMULATION & TO DIVIDE & ELEVATION (m) \\
\hline Columbia & SSE & 0.9 & DS, DW, AV & $15 \mathrm{~km}$ west & $1750-1450$ \\
\hline Daniels & $\mathrm{E}$ & 0.4 & $\mathrm{DS}, \mathrm{WD}$ & $1 \mathrm{~km}$ east & $2230-1970$ \\
\hline Easton & SSE & 2.9 & DS & $75 \mathrm{~km}$ west & $2900-1700$ \\
\hline Foss & $\mathrm{NE}$ & 0.4 & DS & At divide & $2100-1840$ \\
\hline Ice Worm & SE & 0.1 & DS, AV & $1 \mathrm{~km}$ east & $2100-1900$ \\
\hline Lower Curtis & S & 0.8 & DS,WD & $55 \mathrm{~km}$ west & $1850-1460$ \\
\hline Lynch & $\mathrm{N}$ & 0.7 & DS,WD & At divide & $2200-1950$ \\
\hline Rainbow & ENE & 1.6 & DS,AV & $70 \mathrm{~km}$ west & $2040-1310$ \\
\hline Sholes & $\mathrm{N}$ & 0.9 & DS & $70 \mathrm{~km}$ west & $2070-1630$ \\
\hline Yawning & $\mathrm{N}$ & 0.2 & DS & At divide & $2100-1880$ \\
\hline
\end{tabular}

Table 1. The geographic characteristics of the nine glaciers where annual balance has been monitored annually (Figure 2). Accumulation sources: wind drifting $=\mathrm{WD}$, avalanche accumulation $=\mathrm{AV}$, direct snowfall $=\mathrm{DS}$. 
The Cryosphere Discuss., doi:10.5194/tc-2017-62, 2017

Manuscript under review for journal The Cryosphere

Discussion started: 9 May 2017

The Cryosphere

(C) Author(s) 2017. CC-BY 3.0 License.

\begin{tabular}{|c|c|c|c|c|c|c|c|c|c|c|c|}
\hline & $\begin{array}{l}\text { Colum- } \\
\text { bia }\end{array}$ & Daniels & Easton & Foss & $\begin{array}{l}\text { Ice } \\
\text { Worm }\end{array}$ & $\begin{array}{l}\text { Lower } \\
\text { Curtis }\end{array}$ & Lynch & Rainbow & Yawning & Sholes & $\begin{array}{l}\text { South } \\
\text { Cascade }\end{array}$ \\
\hline 1984 & 0.21 & 0.11 & & 0.51 & 0.86 & 0.39 & 0.33 & 0.58 & 0.09 & & 0.12 \\
\hline 1985 & -0.31 & -0.51 & & $\begin{array}{l}-0.69 \\
\end{array}$ & -0.75 & -0.16 & -0.22 & 0.04 & -0.23 & & -1.2 \\
\hline 1986 & -0.2 & -0.36 & & 0.12 & -0.45 & -0.22 & -0.07 & 0.2 & -0.1 & & -0.71 \\
\hline 1987 & -0.63 & -0.87 & & $\begin{array}{l}-0.38 \\
\end{array}$ & $\begin{array}{l}-1.39 \\
\end{array}$ & -0.56 & -0.3 & -0.26 & -0.47 & & -2.56 \\
\hline 1988 & 0.14 & -0.15 & & 0.23 & -0.24 & -0.06 & 0.17 & 0.43 & -0.06 & & -1.64 \\
\hline 1989 & -0.09 & -0.37 & & 0.09 & -0.67 & -0.29 & 0.03 & -0.24 & -0.19 & & -0.71 \\
\hline 1990 & -0.06 & -0.68 & $\begin{array}{l}-0.58 \\
\end{array}$ & -0.27 & -0.92 & $\begin{array}{l}-0.51 \\
\end{array}$ & -0.12 & -0.46 & -0.32 & -0.32 & -0.73 \\
\hline 1991 & 0.38 & -0.07 & 0.41 & 0.3 & 0.63 & 0.04 & 0.36 & 0.44 & 0.23 & 0.48 & -0.2 \\
\hline 1992 & -1.85 & -1.7 & -1.67 & -1.92 & -2.23 & -1.76 & -1.38 & -1.65 & -2.06 & -1.88 & -2.01 \\
\hline 1993 & -0.9 & -0.83 & $\begin{array}{l}-1.01 \\
\end{array}$ & $\begin{array}{l}-0.73 \\
\end{array}$ & $\begin{array}{l}-1.02 \\
\end{array}$ & $\begin{array}{l}-0.48 \\
\end{array}$ & -0.62 & $\begin{array}{l}-0.8 \\
\end{array}$ & -0.66 & -0.96 & -1.23 \\
\hline 1994 & -0.96 & -0.45 & -0.92 & -0.68 & -1.23 & -0.55 & -0.4 & -0.72 & -0.62 & -0.88 & -1.02 \\
\hline 1995 & -0.45 & 0.24 & -0.31 & 0.31 & 0.47 & -0.21 & 0.18 & -0.2 & -0.26 & -0.25 & -0.69 \\
\hline 1996 & -0.62 & 0.45 & 0.22 & 0.34 & 0.57 & $\begin{array}{l}-0.18 \\
\end{array}$ & 0.53 & 0.12 & 0.34 & 0.06 & 0.1 \\
\hline 1997 & 0.35 & 0.88 & 0.53 & 0.5 & 0.76 & 0.27 & 0.62 & 0.51 & 0.5 & 0.42 & 0.63 \\
\hline 1998 & -1.46 & -1.82 & -1.87 & -1.95 & -1.64 & $\begin{array}{l}-1.38 \\
\end{array}$ & -1.97 & -1.49 & -2.03 & -1.56 & -1.8 \\
\hline 1999 & 1.75 & 1.52 & 1.61 & 1.56 & 2.15 & 1.55 & 1.45 & 1.84 & 1.63 & 1.76 & 1.02 \\
\hline 2000 & 0.4 & -0.25 & $\begin{array}{l}-0.1 \\
\end{array}$ & -0.1 & -0.33 & -0.25 & -0.24 & 0.15 & -0.18 & -0.08 & 0.38 \\
\hline 2001 & -1.52 & -1.75 & -1.93 & -1.92 & -2.15 & -1.88 & -1.82 & -1.71 & -1.94 & -1.83 & -1.57 \\
\hline 2002 & 0.6 & -0.18 & 0.18 & 0.1 & 0.05 & 0.13 & -0.13 & 0.12 & 0.26 & 0.21 & 0.55 \\
\hline 2003 & -1.17 & -1.52 & $\begin{array}{l}-0.98 \\
\end{array}$ & -1.35 & -1.4 & -1.25 & -1.2 & $\begin{array}{l}-0.98 \\
\end{array}$ & -1.85 & -1.12 & -2.1 \\
\hline 2004 & -1.83 & -2.13 & -1.06 & -1.94 & -2 & -1.51 & -1.98 & -1.67 & -1.78 & -1.86 & -1.65 \\
\hline 2005 & -3.21 & -2.9 & -2.45 & $\begin{array}{l}-3.12 \\
\end{array}$ & -2.85 & -2.75 & -2.62 & -2.65 & -3.02 & -2.84 & -2.45 \\
\hline 2006 & -0.98 & -1.25 & -0.79 & -1.02 & -1.35 & -1.06 & -1.05 & -0.61 & -0.93 & -0.71 & -1.45 \\
\hline 2007 & -0.37 & 0.12 & 0.26 & $\begin{array}{l}-0.38 \\
\end{array}$ & $\begin{array}{l}-0.62 \\
\end{array}$ & $\begin{array}{l}-0.4 \\
\end{array}$ & 0.07 & 0.2 & -0.13 & 0.29 & -0.21 \\
\hline 2008 & 0.96 & 0.41 & 0.45 & 0.18 & -0.1 & 0.12 & 0.51 & 0.65 & 0.2 & 0.48 & -0.3 \\
\hline 2009 & -0.9 & -1.35 & -2.06 & $\begin{array}{l}-2.02 \\
\end{array}$ & -1.56 & -2.15 & -1.82 & -1.98 & -1.62 & -2.68 & -1.86 \\
\hline 2010 & $\begin{array}{l}-0.21 \\
\end{array}$ & -0.26 & 0.68 & $\begin{array}{l}-0.11 \\
\end{array}$ & $\begin{array}{l}-0.38 \\
\end{array}$ & -0.44 & $\begin{array}{l}-0.34 \\
\end{array}$ & 0.76 & 0.94 & 0.17 & -0.81 \\
\hline 2011 & 1.47 & 1.06 & 1.15 & 1.3 & 1.34 & 0.94 & 0.98 & 1.64 & 1.22 & 1.45 & 1.21 \\
\hline 2012 & 0.38 & 0.75 & -0.16 & 0.25 & 0.15 & $\begin{array}{l}-0.38 \\
\end{array}$ & 0.51 & 0.42 & 0.34 & -0.12 & 0.19 \\
\hline
\end{tabular}


The Cryosphere Discuss., doi:10.5194/tc-2017-62, 2017

Manuscript under review for journal The Cryosphere

Discussion started: 9 May 2017

(c) Author(s) 2017. CC-BY 3.0 License.

(c) (1)

\begin{tabular}{|r|r|r|r|r|r|r|r|r|r|r|r|}
\hline 2013 & -0.78 & -0.15 & -1.58 & -0.5 & -0.76 & -0.85 & -0.4 & -1.85 & -1.15 & -1.7 & \\
\hline 2014 & -0.5 & -0.8 & -1.3 & & -0.62 & -1.35 & -1.12 & -1.94 & -1.53 & -1.65 & \\
\hline 2015 & $\mathbf{- 3 . 4 8}$ & $\mathbf{- 3 . 0 8}$ & $\mathbf{- 2 . 7 8}$ & & $\mathbf{- 3 . 2 5}$ & $\mathbf{- 3 . 4 0}$ & $\mathbf{- 2 . 8 5}$ & $\mathbf{- 3 . 4 5}$ & $\mathbf{- 3 . 0 5}$ & $\mathbf{- 3 . 3 6}$ & \\
\hline Mean & -0.40 & -0.48 & -0.53 & -0.44 & -0.57 & -0.55 & -0.39 & -0.36 & -0.50 & -0.60 & -0.77 \\
& & & & & & & & & & & \\
\hline
\end{tabular}

Table 2 Annual mass balance of North Cascades glaciers 1984-2015. South Cascade Glacier observed by the USGS, all others by the NCGCP. 
The Cryosphere Discuss., doi:10.5194/tc-2017-62, 2017

Manuscript under review for journal The Cryosphere

Discussion started: 9 May 2017

(C) Author(s) 2017. CC-BY 3.0 License.

\begin{tabular}{|c|c|c|c|c|c|c|c|c|c|c|}
\hline & Daniels & Easton & Foss & $\begin{array}{l}\text { Ice } \\
\text { Worm }\end{array}$ & $\begin{array}{l}\text { Lower } \\
\text { Curtis }\end{array}$ & Lynch & Rainbow & Yawning & Sholes & $\begin{array}{l}\text { South } \\
\text { Cascade }\end{array}$ \\
\hline Columbia & 0.90 & 0.88 & 0.92 & 0.89 & 0.92 & 0.90 & 0.91 & 0.92 & 0.90 & 0.83 \\
\hline Daniels & 1.00 & 0.87 & 0.95 & 0.94 & 0.91 & 0.97 & 0.88 & 0.93 & 0.88 & 0.86 \\
\hline Easton & 0.87 & 1.00 & 0.92 & 0.90 & 0.93 & 0.90 & 0.98 & 0.95 & 0.98 & 0.89 \\
\hline Foss & 0.95 & 0.92 & 1.00 & 0.94 & 0.97 & 0.98 & 0.93 & 0.95 & 0.94 & 0.82 \\
\hline Ice Worm & 0.94 & 0.90 & 0.94 & 1.00 & 0.93 & 0.92 & 0.89 & 0.91 & 0.91 & 0.87 \\
\hline $\begin{array}{l}\text { Lower } \\
\text { Curtis }\end{array}$ & 0.91 & 0.93 & 0.97 & 0.97 & 1.00 & 0.95 & 0.94 & 0.94 & 0.96 & 0.81 \\
\hline Lynch & 0.97 & 0.90 & 0.98 & 0.98 & 0.95 & 1.00 & 0.91 & 0.94 & 0.93 & 0.80 \\
\hline Rainbow & 0.88 & 0.98 & 0.93 & 0.93 & 0.94 & 0.91 & 1.00 & 0.96 & 0.98 & 0.80 \\
\hline Yawning & 0.93 & 0.95 & 0.95 & 0.95 & 0.94 & 0.94 & 0.96 & 1.00 & 0.94 & 0.82 \\
\hline Sholes & 0.88 & 0.98 & 0.94 & 0.91 & 0.96 & 0.93 & 0.98 & 0.94 & 1.00 & 0.91 \\
\hline $\begin{array}{l}\text { South } \\
\text { Cascade }\end{array}$ & 0.86 & 0.89 & 0.82 & 0.87 & 0.81 & 0.80 & 0.80 & 0.82 & 0.91 & 1.00 \\
\hline
\end{tabular}

Table 3. Cross-correlation of annual balance on North Cascade glaciers 1984-2014, except for Sholes Glacier and Easton Glacier 1990-2014. South Cascade Glacier observed by the USGS 1985-2012, all other glaciers data from NCGCP.

5

\begin{tabular}{|c|c|c|c|l|l|l|}
\hline & $\begin{array}{l}\text { Winter PPT } \\
\text { (Nov- } \\
\text { March) }\end{array}$ & $\begin{array}{l}\text { April-1 } \\
\text { SWE }\end{array}$ & SWE/PPT & $\begin{array}{l}\text { Ablation } \\
\text { Season } \\
\text { Temperature } \\
\text { (May-Sept.) }\end{array}$ & $\begin{array}{l}\text { Summer } \\
\text { Temperature } \\
\text { (June-Sept.) }\end{array}$ & $\begin{array}{l}\text { Freezing } \\
\text { (Nov.-March) }\end{array}$ \\
\hline 2015 & 2.62 & 0.52 & 0.19 & 18.14 & 18.83 & 1644 \\
\hline $1950-2015$ & 2.5 & 1.14 & 0.46 & 15.94 & 16.86 & 1077 \\
\hline $1984-2015$ & 2.51 & 1.05 & 0.41 & 16.16 & 17.1 & 1144 \\
\hline
\end{tabular}

Table 4. Comparison of 2015 climate conditions to average conditions. 
The Cryosphere Discuss., doi:10.5194/tc-2017-62, 2017

Manuscript under review for journal The Cryosphere

Discussion started: 9 May 2017

(c) Author(s) 2017. CC-BY 3.0 License.

\begin{tabular}{|l|l|l|l|l|l|l|l|l|l|}
\hline & PDO-W & PDO-S & PDO-A & $\begin{array}{l}\text { ENSO- } \\
\text { W }\end{array}$ & ENSO-S & $\begin{array}{l}\text { ENSO- } \\
\mathbf{A}\end{array}$ & $\begin{array}{l}\text { COMB- } \\
\text { W }\end{array}$ & $\begin{array}{l}\text { COMB- } \\
\text { S }\end{array}$ & COMB- \\
\hline 1 & 2015 & 1997 & 2015 & 1998 & 1987 & 1998 & 1998 & 1997 & 1987 \\
\hline 2 & 1987 & 1987 & 1993 & 1987 & 1997 & 1987 & 1987 & 1993 & 2015 \\
\hline 3 & 2003 & 2015 & 2003 & 1992 & 2015 & 1992 & 2015 & 1987 & 1998 \\
\hline 4 & 1998 & 1992 & 1987 & 1995 & 1992 & 2015 & 2003 & 2015 & 1993 \\
\hline 5 & 1988 & 1995 & 1994 & 1988 & 1993 & 1993 & 1988 & 1992 & 1992 \\
\hline
\end{tabular}

Table 5. Ranking of mean PDO, ENSO and PDO+ENSO for 1984-2015 for summer (S), winter (W) and annual (A). 
The Cryosphere Discuss., doi:10.5194/tc-2017-62, 2017

Manuscript under review for journal The Cryosphere

Discussion started: 9 May 2017

(c) Author(s) 2017. CC-BY 3.0 License.

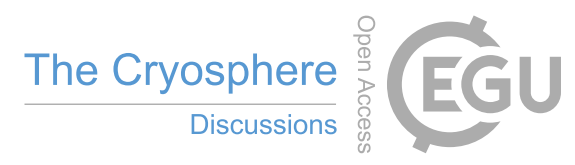

(c) $\underset{\mathrm{By}}{\mathrm{B}}$

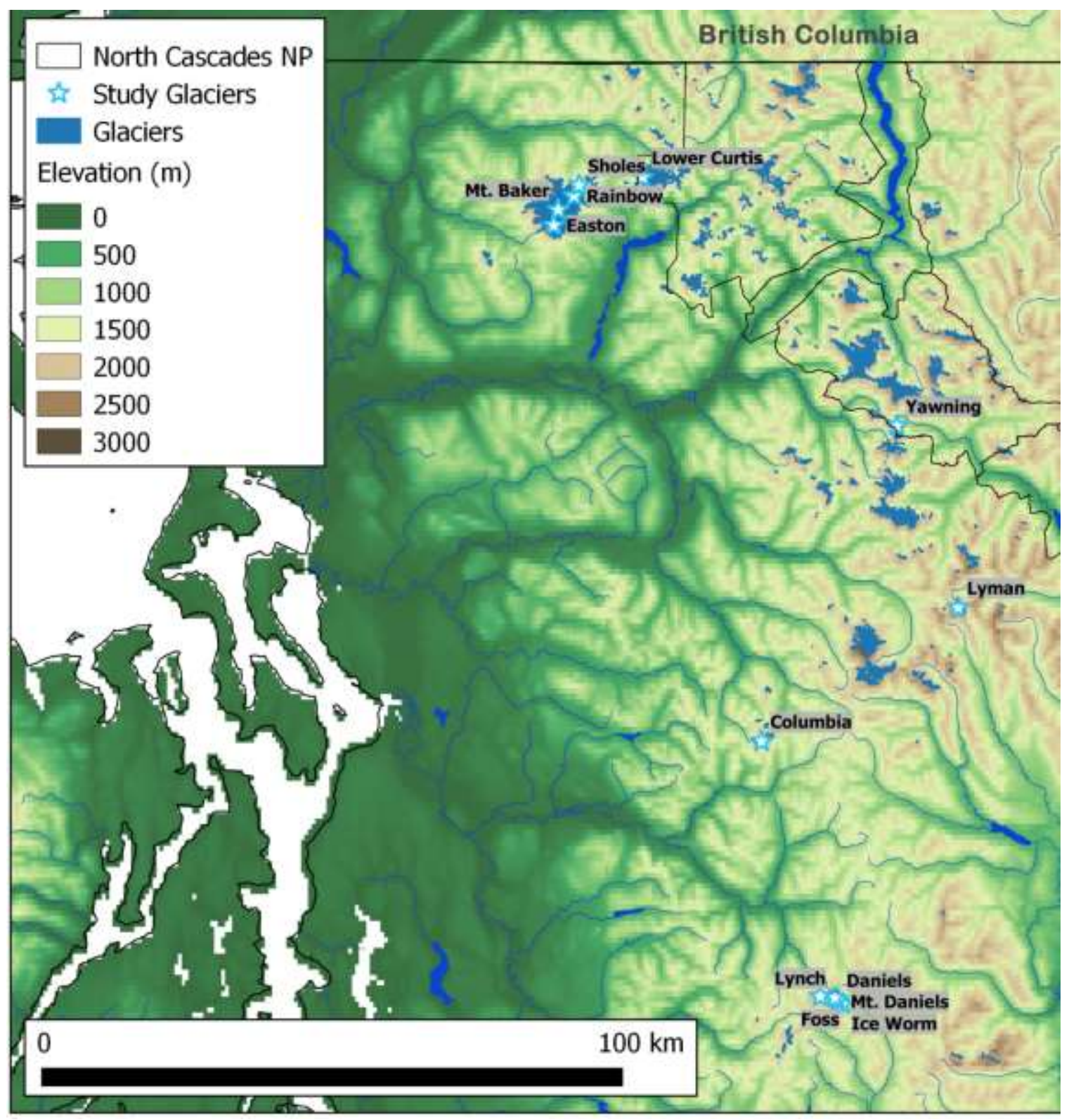

Figure 1. Base map of the North Cascades indicating glacier observed in detail by the North Cascade Glacier Climate Project. 
The Cryosphere Discuss., doi:10.5194/tc-2017-62, 2017

Manuscript under review for journal The Cryosphere

Discussion started: 9 May 2017

(c) Author(s) 2017. CC-BY 3.0 License.
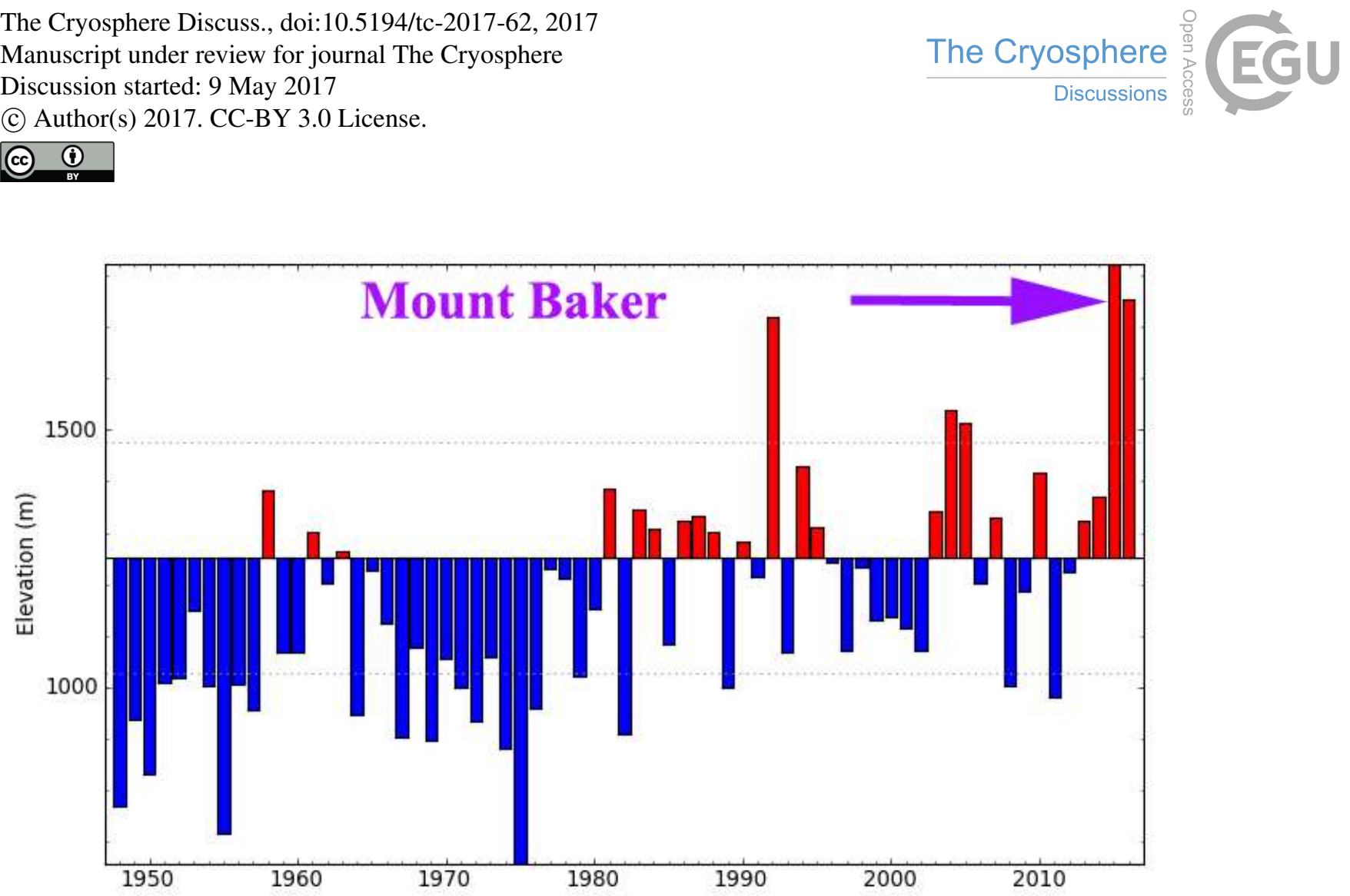

Figure 2. Mean November-March freezing level determined by the North American Freezing Level Tracker for 1948-2016. 
The Cryosphere Discuss., doi:10.5194/tc-2017-62, 2017

Manuscript under review for journal The Cryosphere

Discussion started: 9 May 2017

(C) Author(s) 2017. CC-BY 3.0 License.

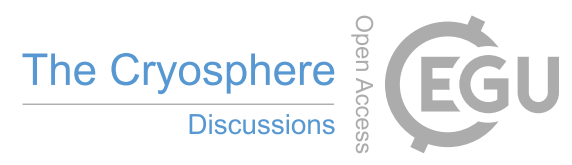

(c) (i)

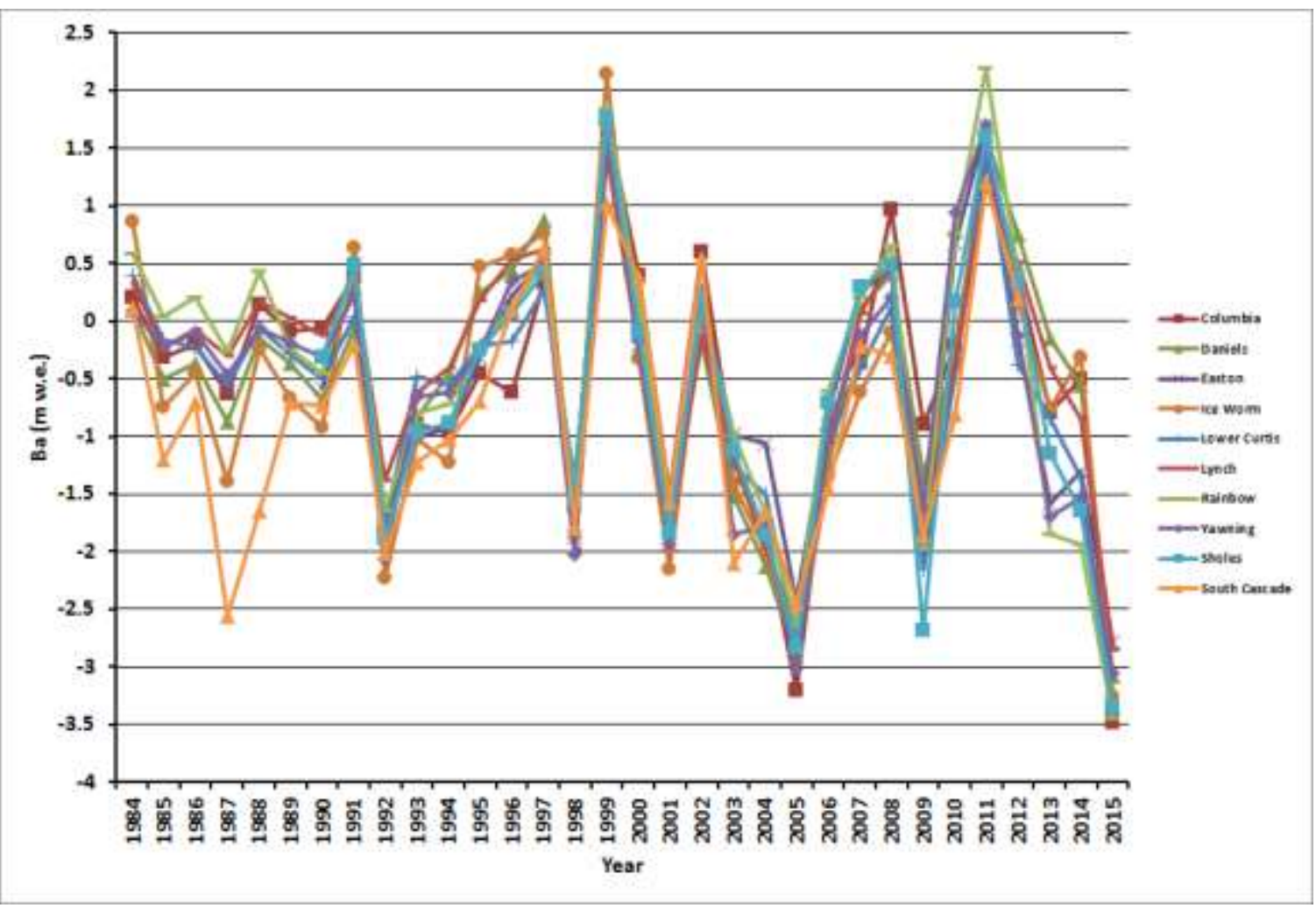

Figure 3. Mean annual balance of North Cascade glaciers, indicating the similar annual response to climate forcing. 
The Cryosphere Discuss., doi:10.5194/tc-2017-62, 2017

Manuscript under review for journal The Cryosphere

Discussion started: 9 May 2017

(c) Author(s) 2017. CC-BY 3.0 License.

(c) (i)

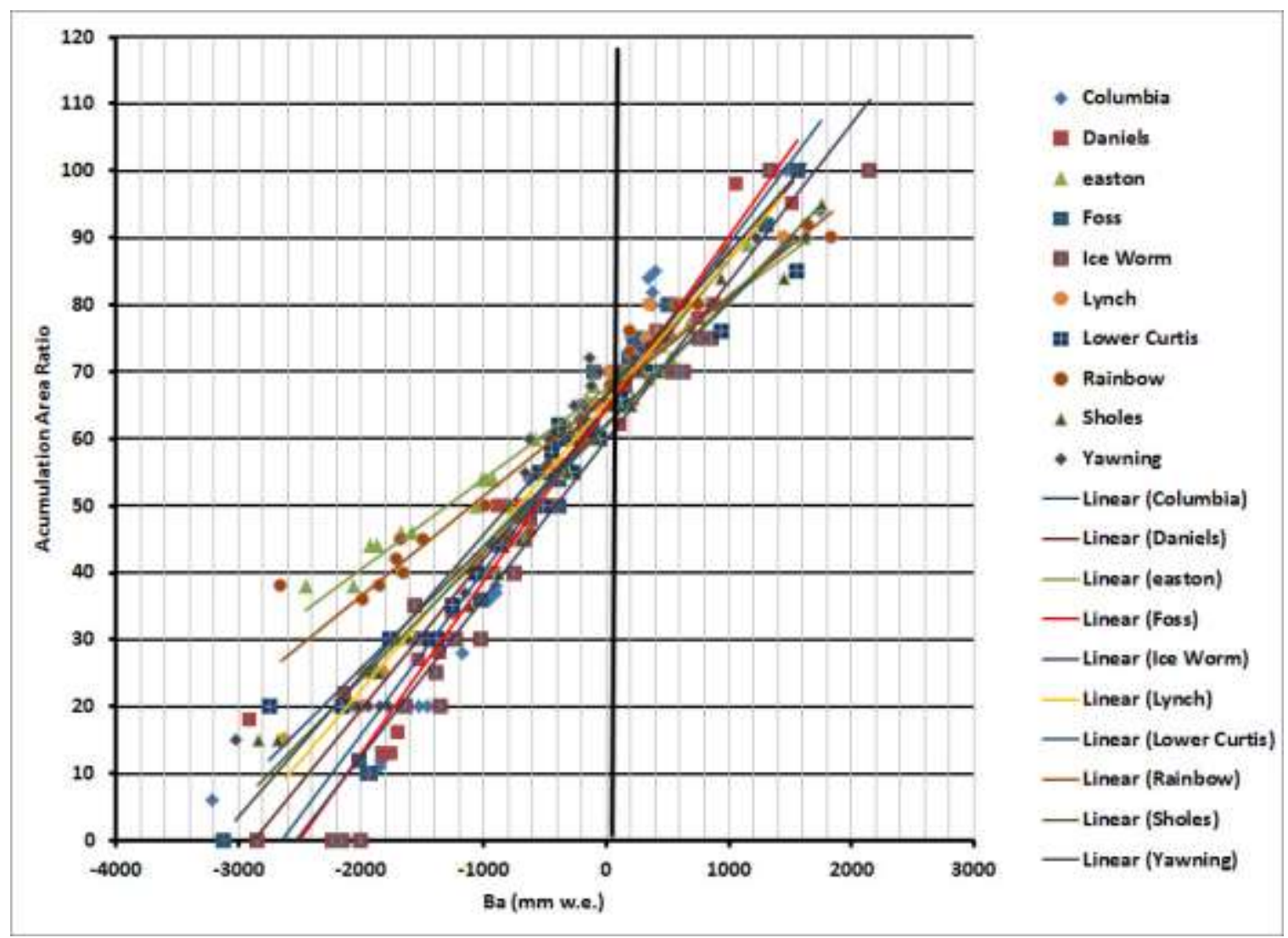

Figure 4. Relationship between annual balance and accumulation are ration on North Cascade glaciers. 
The Cryosphere Discuss., doi:10.5194/tc-2017-62, 2017

Manuscript under review for journal The Cryosphere

Discussion started: 9 May 2017

(C) Author(s) 2017. CC-BY 3.0 License.
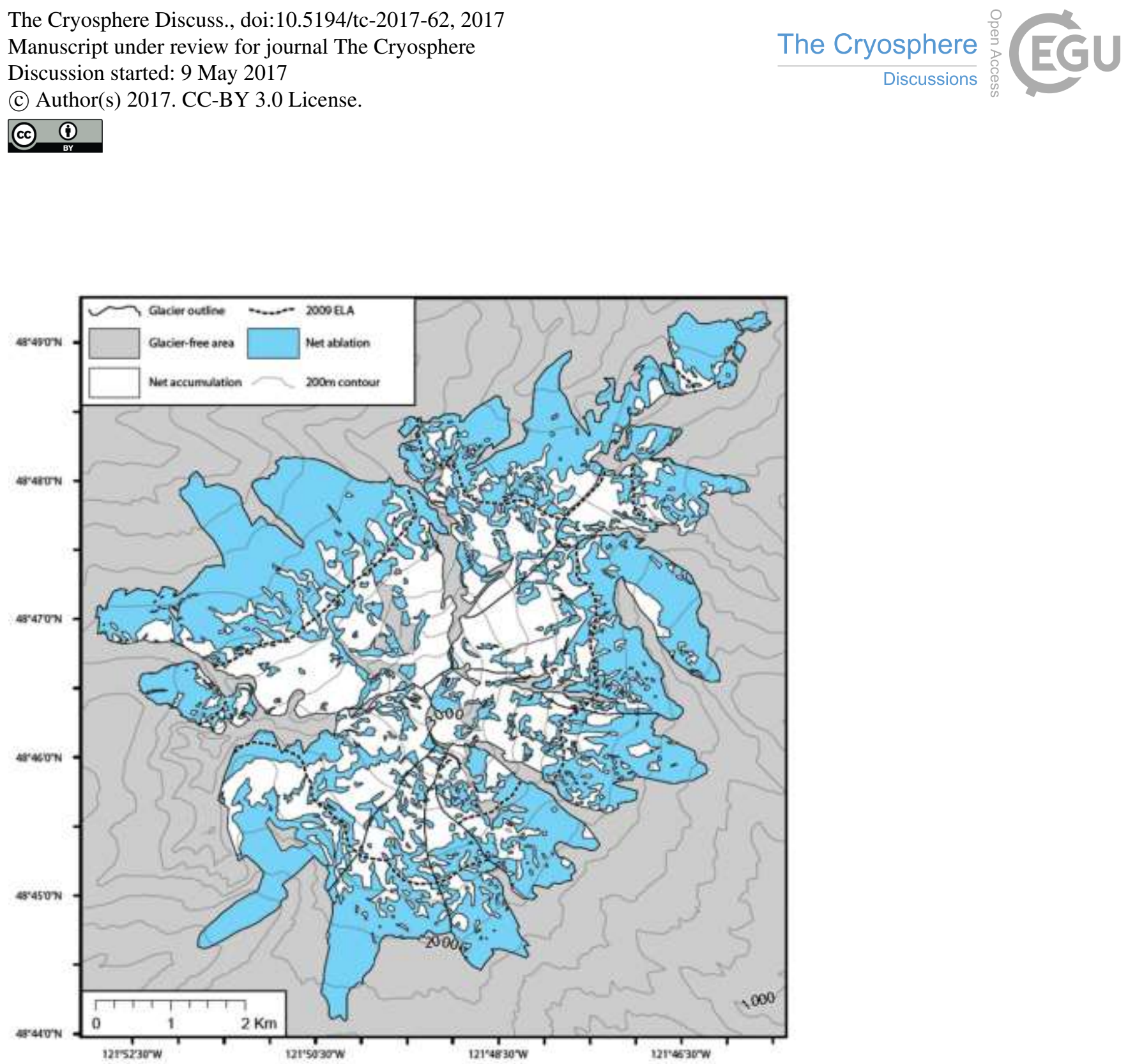

Figure 5. Map of the accumulation area on Mount Baker in 2009, used to determine AAR. 
The Cryosphere Discuss., doi:10.5194/tc-2017-62, 2017

Manuscript under review for journal The Cryosphere

Discussion started: 9 May 2017

(c) Author(s) 2017. CC-BY 3.0 License.

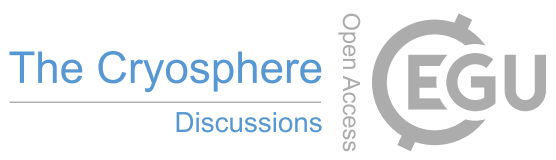

(c) $\underset{\mathrm{BY}}{(i)}$

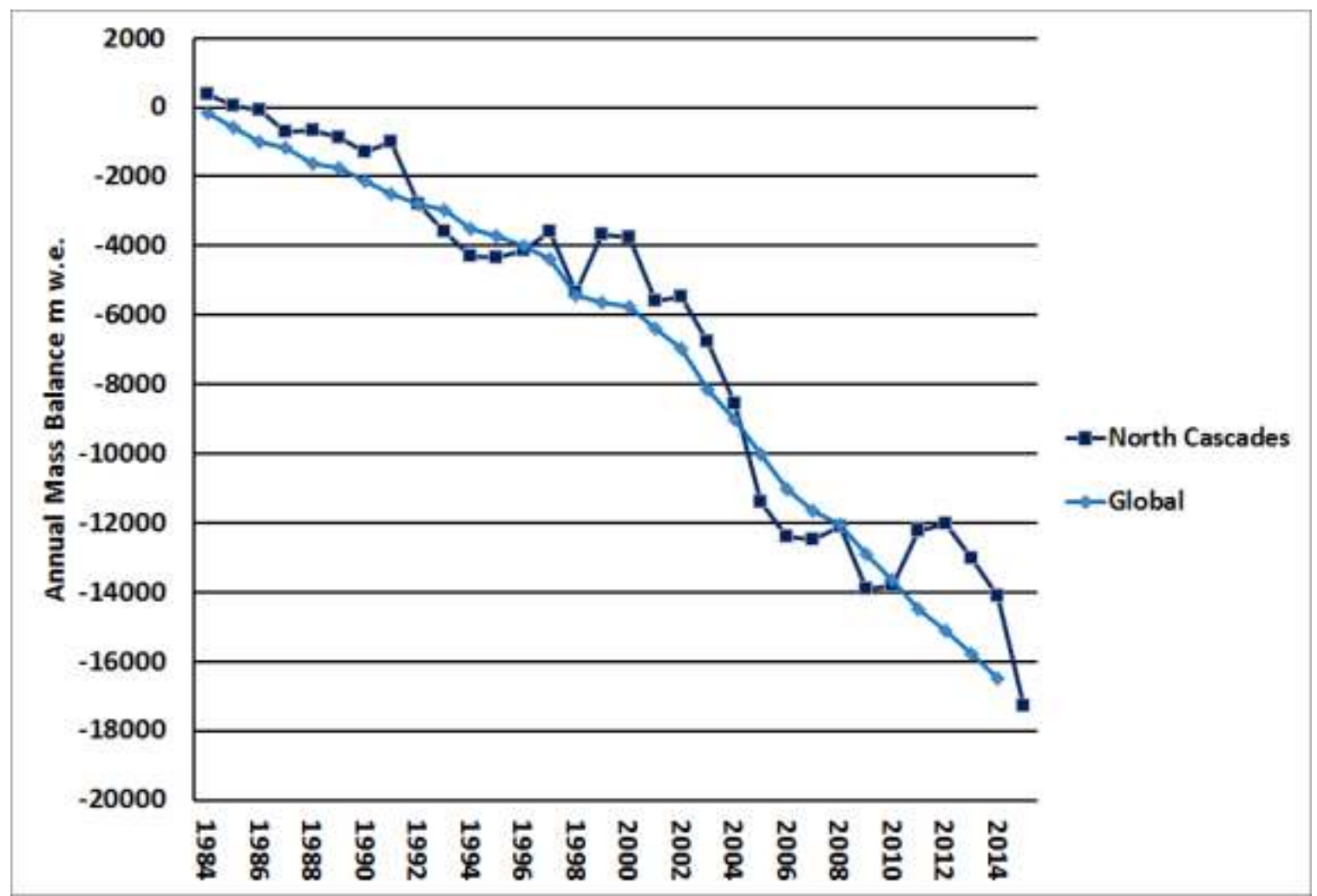

Figure 6. Cumulative mass balance for North Cascade glaciers observed by NCGCP and the WGMS Global reference glacier group. 
The Cryosphere Discuss., doi:10.5194/tc-2017-62, 2017

Manuscript under review for journal The Cryosphere

Discussion started: 9 May 2017

(c) Author(s) 2017. CC-BY 3.0 License.

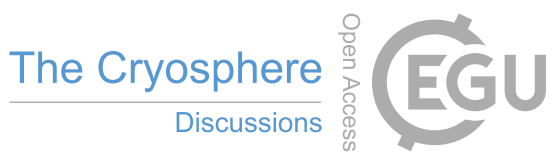

(c) (i)

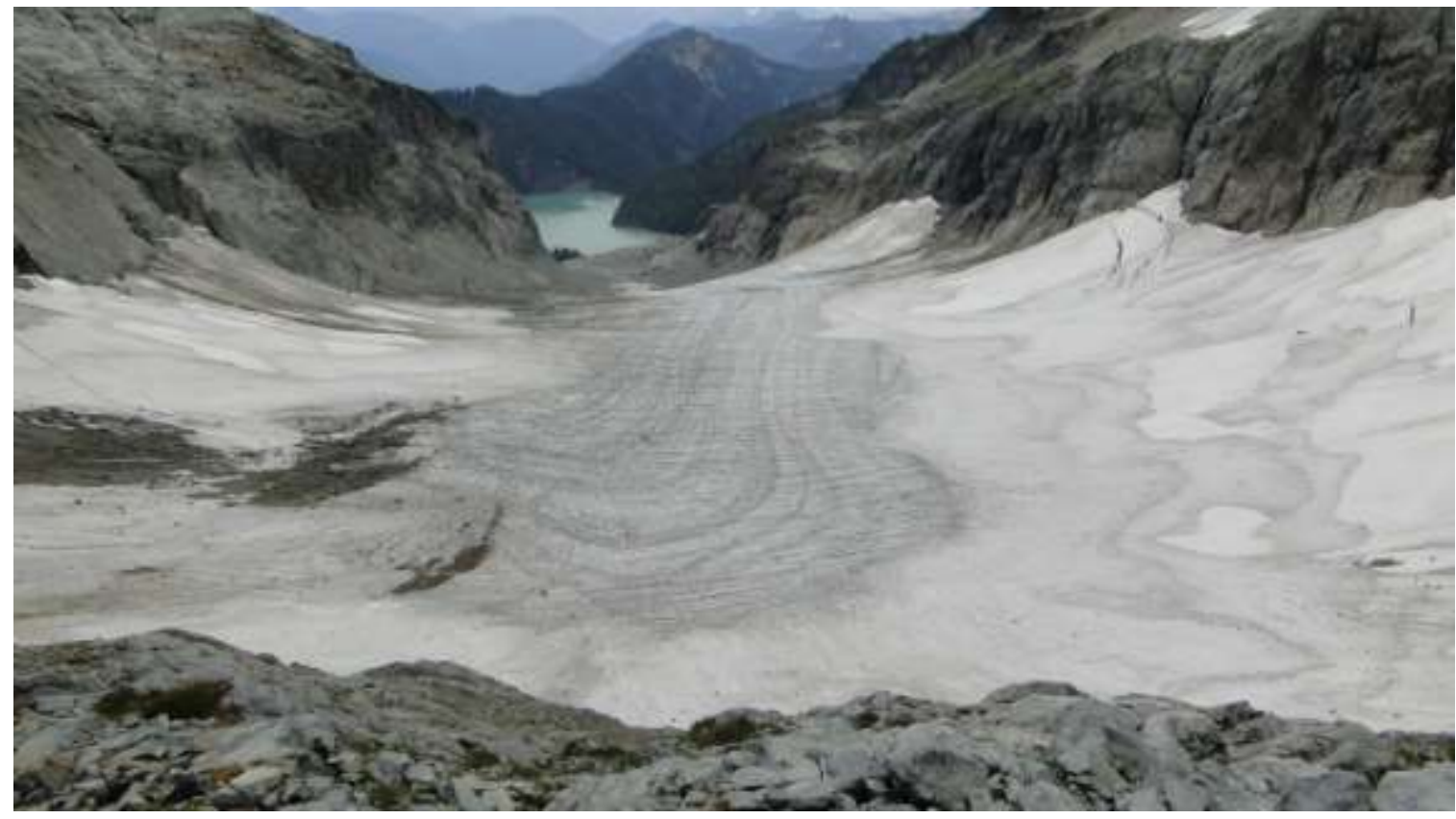

Figure 7. Columbia Glacier from above the accumulation zone on August 1, 2015, with seven weeks left in the ablation season, 5 little 2015 accumulation is retained. 
The Cryosphere Discuss., doi:10.5194/tc-2017-62, 2017

Manuscript under review for journal The Cryosphere

Discussion started: 9 May 2017

(c) Author(s) 2017. CC-BY 3.0 License.

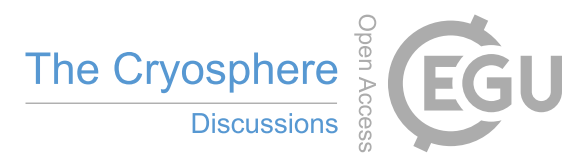

(c) $\underset{\mathrm{By}}{\mathrm{g}}$

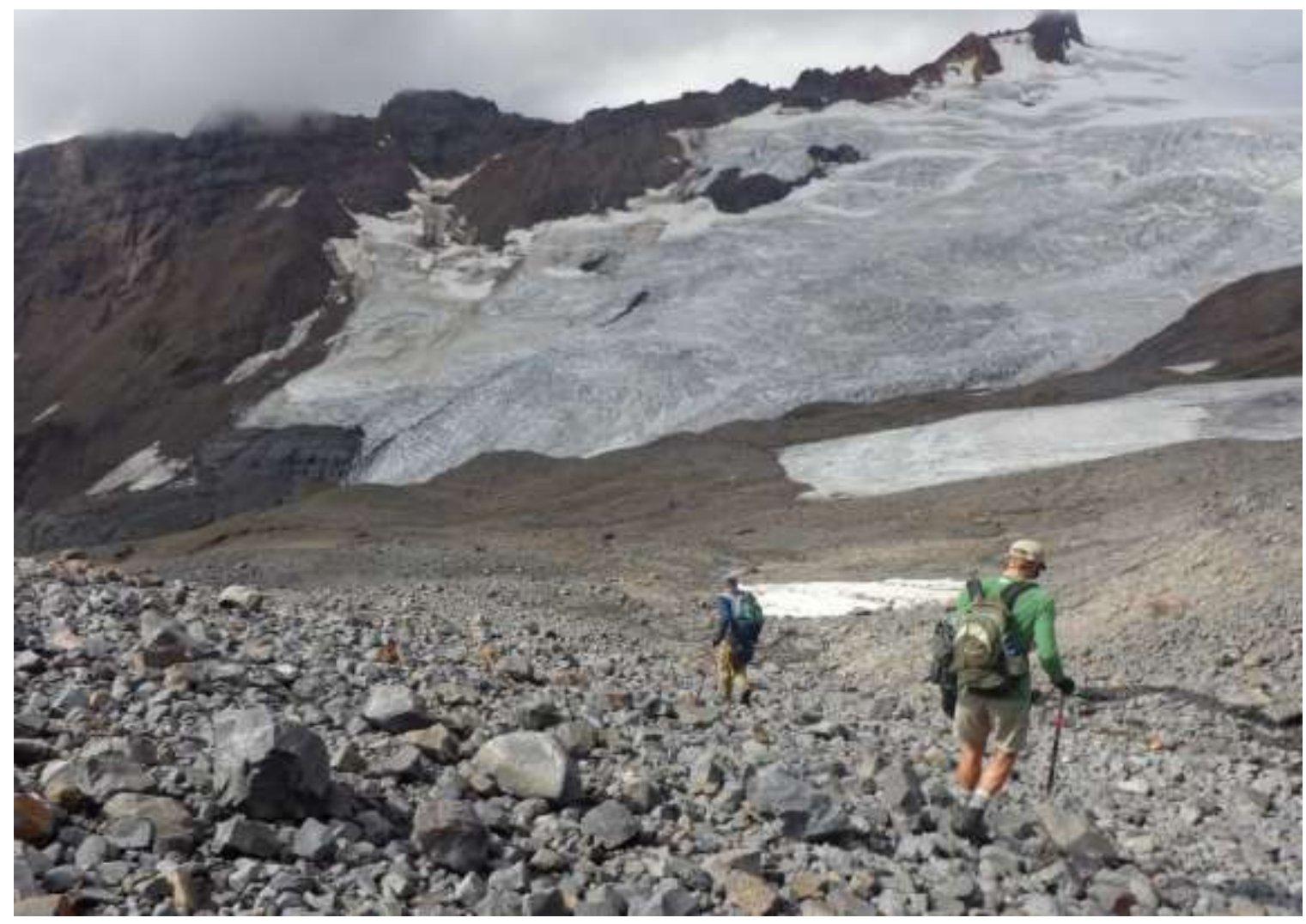

Figure 8. Rainbow Glacier on August, 6 2015, with most of the glacier bare of retained snowpack, where typically 3+ meters would remain. The transient snowline is at $2000 \mathrm{~m}$, higher than the typical end of season snowline. 
The Cryosphere Discuss., doi:10.5194/tc-2017-62, 2017

Manuscript under review for journal The Cryosphere

Discussion started: 9 May 2017

(c) Author(s) 2017. CC-BY 3.0 License.

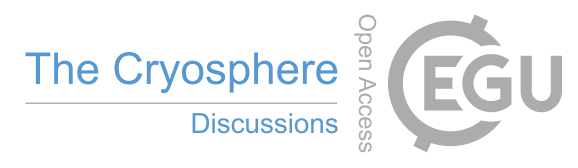

(c) $\underset{\mathrm{By}}{\mathrm{B}}$

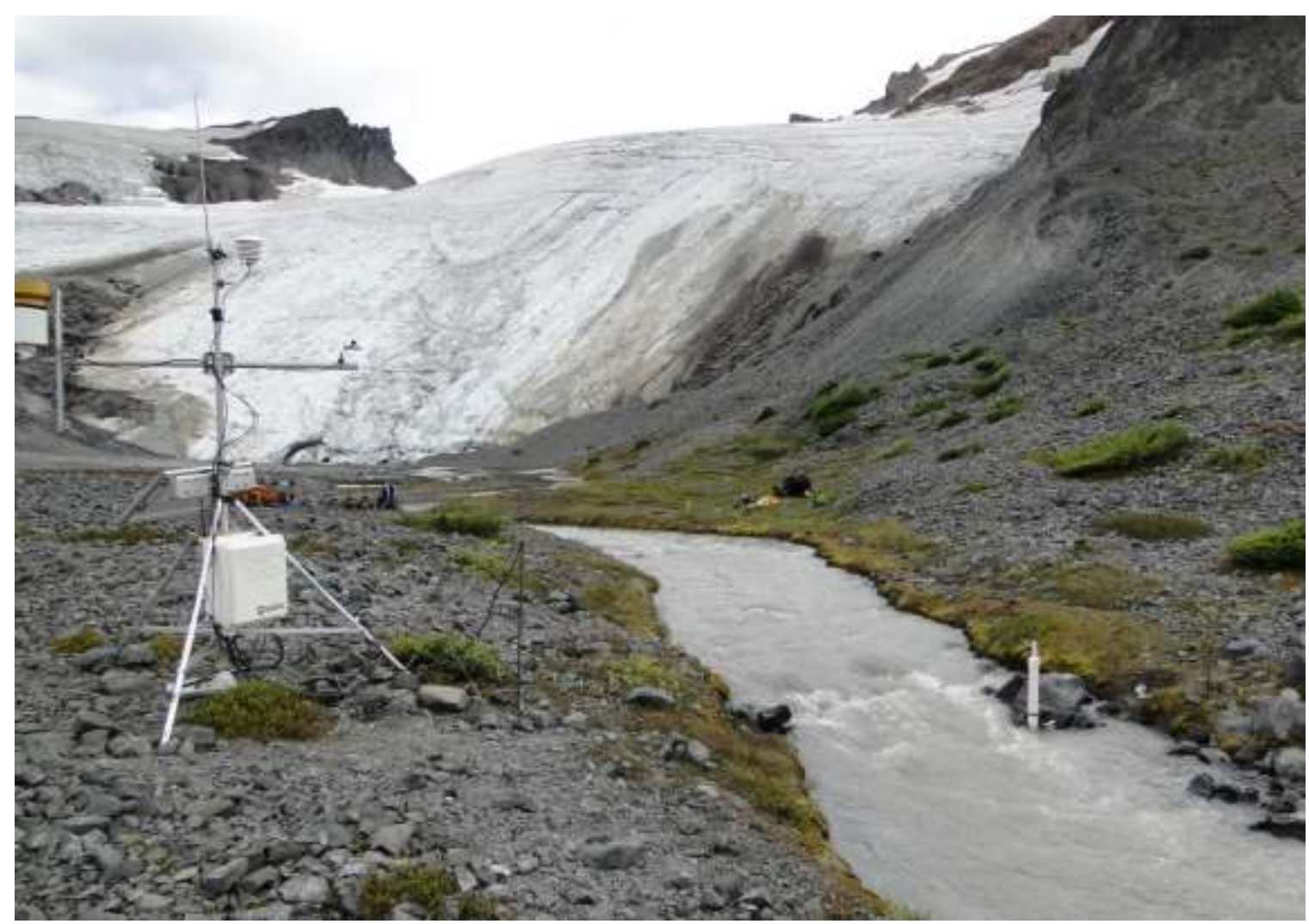

Figure 9 Lack of retained snowpack on Aug. $8^{\text {th }}, 2015$ on Sholes Glacier, with the discharge and weather station in foreground. 